\title{
The Effect of Oxygen Therapy With Nasal Cannula to Oxygen Saturation Through Oximetry Examination For Patients With Heart Failure At Emergency Departmemt of RSUD Ulin Banjarmasin 2018
}

\author{
Rifky Hidayat $^{1}$, Hanura Aprilia ${ }^{2}$ \\ Universitas Muhammadiyah Banjarmasin, South Kalimantan, Indonesia \\ Corresponding author: rifkyhidayat2803@gmail.com
}

\begin{abstract}
Background: Heart Failureis a major cause of morbidity and mortality worldwide. In recent years the incidence of HF has increased and the risk of heart failure is increasing all the time.

Purpose: To find outthe effect of oxygen therapy by nasal cannula to the oxygen saturation through the examination oximetry in patients with HF in the ER Hospital Ulin Banjarmasin.

Method: The study design with pre-experimental design to design one group pretestposttest design, hearth Failure population all patients with shortness of breath in the emergency room, the study sample using accidental sampling technique. Instrumen using observation sheets, examination using pulse oximetry using univariate and bivariate analysis by paired T-test.
\end{abstract}

Results: The average oxygen saturation before treatment is given after $88.87 \%$ and $95.96 \%$ obtained by the treatment, an increase in oxygen saturation. There is the influence of oxygen therapy by nasal cannula to the oxygen saturation through the examination oximetry in patients with $\mathrm{HF}$ obtained value $\rho$ value $=0,000 \leq \alpha=0.05$ Conclusion: By giving oxygen therapy, it can increase saturation oxygen for patients with heart failure

Keywords: Heart Failure, Nasal Cannula, Oxygen therapy, oximetry.

Received: February 21, 2019; Revised : March 9, 2019; Accepted: March 17, 2019

How to Cite: Hidayat, R., \& Aprilia, H. (2019). The Effect of Oxygen Therapy With Nasal Cannula to Oxygen Saturation Through Oximetry Examination For Patients With Heart Failure At Emergency Departmemt of RSUD Ulin Banjarmasin 2018. Journal of Nursing Practice. 2(2). 109-115. https://doi.org/10.30994/jnp.v2i2.53 


\section{BACKGROUND}

Heart Failure(HF) is defined as a function of structural abnormalities of the heart or a heart failure in distributing oxygen as needed in tissue metabolism, although the normal filling pressure or an increased filling pressures (Mc Murray et al, 2015). Congestive heart failure is a clinical syndrome prognosis caused by inability of the heart to pump blood to meet the metabolic needs of the body (Dipiro et al, 2015).

Data were obtained from the WHO in 2015, heart disease is the number one cause of human deaths in low- and middle-income countries accounted for $>75 \%$, or about 7.5 million cases of all deaths in the world. WHO in 2016, an increase of 17.5 million cases of death due to heart disease. Of the incidence rate in general it can be concluded that during the last 2 years has increased about cardiovascular disease.

HF prevalence of the disease in Indonesia in 2015 amounted to $0.13 \%$, or about 229696 people, while based on symptoms by $0.3 \%$, or about 530068 people. In Indonesia Health Profile 2016, HF caused 113395 people hospitalized, and 116431 people outpatients in all hospitals in Indonesia. While the prevalence of HF in Indonesia in 2017 has increased, reaching 420449 hospitalized patients experiencing throughout the hospital. Data prevalence of HF in Indonesia in each tahaunnya increased number of patients (MoH RI, 2017).

Research by Widiyanto \& Yamin (2014) in which they examined the oxygen therapy to changes in oxygen saturation through the examination oximetry in patients with myocardial infarction Acute (IMA) showed that there are significant oxygen therapy to changes in oxygen saturation in patients with myocardial infarction Acute (IMA) is too low, then it will lead to hypoxia proficiency level where it can cause vasodilation of cerebral blood vessels which will be followed by an increased rate of blood flow to the brain increases so that these conditions will result in an increase in intracranial pressure (Hendrizal, 2014).

Studies that prove the effect of oxygen therapy Terry \& Weaver (2013) states that the benefits of nasal cannula delivery systems include oxygen administration means a comfortable and easy with concentrations of up to $44 \%$. This equipment is cheaper, easier for activity / mobility of patients, and the system is practical for long term use. Oxygen therapy with nasal cannula affect changes in oxygen saturation levels. It meetsto achieve the metabolic needs of the body so as to meet the oxygen requirements(Wilkinson \& Ahern, 2012).Giving oxygen may increasing the amount of oxygen entering the lungs keparu. The statement was supportedFebriyanti journals, et al. (2017)that the nasal prongs oxygenation therapy can restore oxygen saturation of hypoxic conditions were severe to mild hypoxia and hypoxia-being mild to moderate significantly to its normal condition.

\section{OBJECTIVE}

This Research aim to find outthe effect of oxygen therapy by nasal cannula to the oxygen saturation through the examination oximetry in patients with $\mathrm{HF}$ in the ER Hospital Ulin Banjarmasin.

\section{METHODS}

This study design is a kind of pre-experimental design to design one group pretest-posttest desin sampling technique using accidental sampling. The purpose of this study to determine the effect of oxygen therapy by nasal cannula to the oxygen 
saturation through the examination oximetry in patients with heart failure in Emergency department RSUD Ulin Banjarmasin 2018.

The study population in this study are patients with heart failure who experience shortness of breath which is obtained when the study amounted to 28 respondents and the sample met the criteria were 23 respondents in Banjarmasin Ulin General Hospital emergency room. The tools used in this research is the pulse oximetry and observation sheet.

The variables of this research is the oxygen therapy and oxygen saturation. Analysis consisted of univariate and bivariate analysis by paired T-test. This study meets the requirements of ethics and have obtained permission from the ethics committee of the Faculty of ethical clearance Keperawatn and Health Sciences, University of Muhammadiyah Banjrmasin No. 143 / UMB / KE / X / 2018.

\section{RESULT}

The results showed carry oxygen therapy affect the oxygen saturation changes in heart failure patients.

\section{a. Univariate analysis}

Oxygen saturation before and after administration of oxygen by nasal cannula therapy.

\begin{tabular}{cccc}
\hline $\begin{array}{c}\text { Treatment with nasaal } \\
\text { cannula oxygen } \\
\text { therapy }\end{array}$ & pretest & posttest & Difference \\
\hline mean & 88.87 & 95.96 & 7.09 \\
\hline SD & 4,115 & 3,126 & 2.678 \\
\hline
\end{tabular}

Table 1. Oxygen saturation before and after administration of oxygen by nasal cannula therapy.

According to the table indicates that the oxygen saturation of the respondents before therapy oskigen (pretest) average (88.87\%) and after the administration (posttest) average $(95.96 \%)$. Changes in the oxygen saturation of respondents on average $(7.09 \%)$.

\section{b. Bivariate analysis}

\begin{tabular}{cccc}
\hline & & Kolmogorov-Smirnova & \\
& statistics & Df & Sig. \\
\hline pretest &, 151 & 23 &, 189 \\
posttest &, 239 & 23 & .001 \\
\hline
\end{tabular}

Teble 2. Kolmogorov-Smirnov normality test 
According to the table shows that the output One Sample Kolmogorov-Smirnov Test showed that the probability or significance value of $0.189>0.05$. It can be concluded that the data were normally distributed.

\begin{tabular}{cccccc}
\hline $\begin{array}{l}\text { Oxygen therapy } \\
\text { treatment }\end{array}$ & mean & SD & $\mathrm{t}$ & $\mathrm{df}$ & $\rho$ value \\
\hline Before and after & -7.087 & 2.678 & 12.690 & 22 & 0,000 \\
\hline
\end{tabular}

Table 3. analysis of paired T-test

Based on the above tabe of the statistical test Paired T-Test the group of respondents was seen between before and after treatment. The results of this statistical test output value obtained $\rho$ value $=0,000 \leq \alpha=0.05$, thus Ho is rejected and Ha accepted, meaning No effect of oxygen therapy by nasal cannula to the oxygen saturation through the examination oximetry in patients hearth failure (HF).

\section{DISCUSSION}

\section{Oxygen Saturation Levels Before and After Treatment Awarded}

The results showed thatthe average oxygen saturation before treatment is given after $88.87 \%$ and $95.96 \%$ obtained treated. Visible changes to increase oxygen saturation values between before and after treatment was $7.09 \%$. The results showed that a change in the oxygen saturation in patients hearth failure (HF). Hemoglobin oxygen saturation is a presentation that binds with oxygen in the arteries, normal oxygen saturation is between $95-100 \%$. In medicine, okseigen saturation (SO2), often referred to as "SATS", to measure the percentage of oxygen yangdiikat by hemoglobin in the blood stream. At low oxygen partial pressure, most of deoxygenated hemoglobin, the intention is the process of distributing oxygenated blood from the arteries to the body's tissues (Hidayat, 2014).

One of the factors that influence the occurrence of heart failure with symptoms of shortness of breath is a sign of age, this is due to physiological changes in the heart that occur along with increasing age. The results showed that the majority of the respondent's age was at the age of 46-55 years as many as 11 people (47.82\%) which is an elderly early age. In line with the results of research conducted Asmoro (2017) the majority of respondents aged 45-60 years (Djuantoro, 2014).

Some causes of heart failure in older age is hypertension that stimulate the heart to work harder even exceed its capacity. Age affects the incidence of heart failure this is due to old age function of the heart is decreased and changes occur in the cardiovascular system such as narrowing of the arteries by plaque, the heart wall thickening, and chamber chambers of the heart decreases (Kusuma, 2007) in (Asmoro, 2017 ). The rise in the risk of cardiovascular disease may also be influenced by gender (Djuantoro, 2014). Based on the results of the study showed that the majority of respondents are male sex as many as 13 people (56.52\%). That men also have a greater risk to cardiovascular morbidity and mortality. There was also affected due to the relaxed lifestyle such as lack of activity is closely linked to obesity in terms of energy released at least compared with input so that nutrients eaten will be stored and stacked in the body as fat (Djuantoro, 2014).

In addition to men also due to factors which the state smoking habits of the heart and lungs those who smoke will not work efficiently. Cigarette smoke contains nicotine which spur spending substances such as adrenaline. Smoking is a factor for 
hypertension, it will cause a person at risk for HF by three-fold. (Djuantoro, 2014). The statement was supported theoryWilkinson \& Ahern (2012) which states that smoking is also a risk factor for heart disease, smoking speeds up the heart rate, lowering the heart's ability to carry and deliver oxygen and can cause blood clots.

Most respondents worked as a trader with the number $7(30.43 \%)$. This is consistent with the theory EMBI (2008) states that the work has a very important role in meeting the needs of human life, particularly social and psychological needs. Someone traders tend to have unstable economy, triggering anxiety and stress in meeting the daily needs that lead to unhealthy lifestyles.

Based on the above facts and theories that support researchers assume that factors that influence the occurrence of heart failure include age, gender, and occupation. The older it is increasingly decreased heart function and changes occur in the cardiovascular system including heart failure. Besides men have a greater risk of the occurrence of heart failure and shortness of breath because smoking causes lung may not work optimally. One's job also affects the occurrence of heart failure because of factor incomes to make ends meet and take a decision to go to the health service.

\section{Effect of oxygen therapy with nasal cannula}

In the research that has been conducted shows that the results of this statistical test output value obtained $\rho$ value $=0,000 \leq \alpha=0.05$, thus Ho is rejected and $\mathrm{Ha}$ accepted, meaning No effect of oxygen therapy by nasal cannula to the oxygen saturation through the examination oximetry in patients hearth failure (HF).

Therapy used in this study is the oxygen therapy via nasal cannula. That one action to prevent HF is collaboration with nasal oxygen therapy cannule aiming to maintain tissue oxygenation remain adequate and may decrease myocardial work due to lack of oxygen supply. This could improve the preparation myocardial demand for oxygen as against hypoxia (Harahap, 2005)

Oxygen therapy given to patients by using a cannula to increase the volume of oxygen in this case FiO 2 that enters the lungs indirectly also increase the diffusion capacity of lung and increases the partial pressure of $\mathrm{O} 2$ (PO2) will be getting a lot of oxygen bound by the hemoglobin is delivered kejaringan arround so that the body can restore normal oxygen saturation kenilai. Oxygen therapy given to patients by using a cannula (Widiyanto and Yamin, 2014),

Oxygen is given through a nasal cannula at a flow rate of 2 liters / minute to 4 liters / minute at a concentration of $24 \%-44 \%$. The flow velocity of more than 6 liters / min is rarely used because its effect causes dry mucous and also because of the amount of oxygen given relatively little bigger (Harahap, 2005).

The tool used is the pulse oximetry consisting of two diode emitters of light (one red light and one infrared light) on one side of the probe, both this diode transmits red and infrared light passed through the blood vessels, usually on the fingertip or earlobe, to the photodetector on the other side of the probe (Welch, 2005).

According to researchers based on facts and theories that support that oxygenation highly associated application interventional therapy to maintain oxygenation. The need to maintain the stability of the $\mathrm{PaO} 2$ with oxygen therapy which increases the FiO 2 ratio will also increase the $\mathrm{PaO} 2$ which is a factor that will determine oxygen saturation, where the high $\mathrm{PaO} 2$ hemoglobin carries more oxygen and at a low $\mathrm{PaO} 2$ hemoglobin carries little oxygen. Achievement of oxygen saturation (SpO2); the concentration of oxygen given. 
In addition to the provision of oxygen therapy may also affect the position of the oxygen saturation changes. Positioning semi-Fowler and Fowler both improve oxygen saturation, only the increase staurasi oxygen is more common in semi-Fowler position because the most effective position for clients with illness cardiopulmonary is semiFowler position with the degree of inclination of $45^{\circ}$, using the force of gravity to assist the development of the lungs and reduce the pressure on the abdomen on the diaphragm (Potter \& Perry, 2006)

Heart Failure In patients often experience shortness of breath. When an attack is usually the client feels claustrophobic claustrophobic and unable to sleep lying down position, but must be in a sitting or semi-sitting position. To relieve airway constriction and meet oxygen in the blood. The most effective position for clients with cardiopulmonary disease is semi-Fowler or Fowler's position is by using gravity to help the development of the lungs and reduce the pressure on the abdomen diafraghma (Potter \& Perry, 2006).

Based on the survey results revealed that the position of the semi-Fowler and Fowler position is a position that can increase oxygen saturation in cardiac patients because this position can reduce pressure on the diaphragm but the results of this study, the results of the study that administration of semi-Fowler position turned out to be more Effective than Fowler position although both rely on gravity but with a semiFowler's position because it would be more effective at reducing the pressure on the diaphragm.

\section{CONCLUSION}

The average oxygen saturation before treatment is given after $88.87 \%$ and $95.96 \%$ obtained by the treatment, an increase in oxygen saturation. There is the influence of oxygen therapy by nasal cannula to the oxygen saturation by oximetry checks on hearth failure patients get value $\rho$ value $=0,000 \leq \alpha=0.05$. The results of this study can be used as a reference SOP heart failure patient management in nursing action by increasing the oxygen saturation, this study are expected to provide input to the profession of nursing science particularly in developing independent actions of nurses in fulfilling the needs of oxygenation

\section{REFERENCES}

Asmoro, DA (2017). Nursing care in patients with Congestive Heart Failure (CHF) With Rainfall Decrease Heart Through Pemnerian Oxygen Therapy In ICU PKU Muhammadiyah Deal.

Dipiro, JT, Barbara, GW, Terry., LS, \& Cecily, VD (2015). Pharmacotherap Handbook Eight Edition. New York: The McGraw-Hill Companies. P. 82-94.

Djuantoro, D. (2014). Buju Pathophysiology Made Incredibly Easy Festive illustration. South Tangerang: Binarupa Script.

Harahap, IA (2005). Oxygenation In A Nursing. Issue 2 Jakarta: Salemba Medika.

Hariyanto, A., Hadisaputro, S. \& Supriyadi. (2015). Effectiveness of Foot Hand Massage Physiological Response Against Pain And Intensity of Acute Myocardial Infarction Patients: Study In Space ICCU Rsud.Dr. Isaac Tulungagung. J. Nursing And Midwifery (JIKK), Vol. II, No. 3, Hal: 113-122. available InHttp://Download.Portalgaruda.Org/ (Accessed Date August 21, 2018). 
Hendrizal. (2014). Factors Associated with Smoking Behavior. Yogyakarta: Nuhu Medika.

Hidayat, AAA (2014). Midwifery Research Methods and Data Analysis Techniques. Jakarta: Salemba Medika.

MoH RI. (2017). Heart Failure panyakit recapitulation of the whole Indonesia.

Mcmurray, JJJV (2015). Improving Outcomes In Heart Failure: A Personal Perspective. European Heart Journal. Number 36, Page: 3467-3470. available In<TTPs: //Pdfs.Semanticscholar.Org/ (Accessed On 21 August).

Potter \& Perry. (2006). Fundamentals Of Nursing Fundamentals of Nursing 1, Issue 7. Jakarta: Salemba Medika.

Terry, C. L., \& Weaver, A. (2013). Critical Nursing. Yogyakarta: Rapha.

Welch, J. (2005). Pulse Oximetry. Biomedical Instrumentation And Technology, 125130.

Widyanto, B. \& Yamin, LS (2014). Against Oxygen Therapy Oxygen Saturation Changes Through examination Miokar oximetry in patients with acute infarction (AMI). Journal of Nursing PPNI Central Java Page 138-143.

Wilkinson, JM \& Ahern NR (2012). Handbook of Nursing Diagnosis NANDA Diagnosis Interventions NIC NOC Results Criteria Ninth Edition. Jakarta: EGC. 